УДК 371.134:78(07)

DOI:

Світлана Лисюк, кандидат мистеитвознавства, дочент кафедри загального та спеціалізованого фортепіано, Одеської національної музичної академії імені А.В. Нежданової

Свген Лисюк, Заслужений праџівник культури Украӥни, доцент кафедри спеціального фортепіано, Одеської національної музичної академії імені А.В. Нежданової

\title{
ПРОБЛЕМА СУЧАСНОГО АРАНЖУВАННЯ ТА ПЕРЕКЛАДАННЯ ГІТАРНИХ ТВОРІВ
}

У статті розглянуто основні напрями аранжування гітарних творів. Проаналізовано процес використання аранжування для гітари, щуо дозволяє спрямувати зусилля викладачів на пробудження самостійної творчості учнів шкіл естетичного виховання, на поступове розкриття і розвиток музичних здібностей дітей та професійний ріст їхнього педагога-аранжувальника. Обтрунтовано перекладання інструментальних, вокальних, оркестрових творів для гітари, яке є творчо активною працею, пов'язаною з вирішенням естетичних завдань.

Ключові слова: аранжування; музична освіта; перекладання музичних творів; гітарні музичні твори; обробка гітарних творів.

Jim. 8.

Svitlana Lysyuk, Ph.D. (Art Studies), Associate Professor of the General and Specialized Piano Department, Odesa Antonina Nezhdanova National Academy of Music Yevhen Lysyuk, Honored Worker of Culture of Ukraine,

Associate Professor of the Special Piano Department, Odesa Antonina Nezhdanova National Academy of Music

\section{THE PROBLEM OF MODERN ARRANGEMENT AND TRANSLATION OF GUITAR WORKS}

The article considers the problem of processing, translation of the author's music and the importance of arranging the guitar works in the development of musical abilities of students of schools of aesthetic education.

It is substantiated that the use of arrangements for the development of the students' musical abilities is determined by the musical life itself, its practice, and the needs of constant active updating of the pedagogical repertoire. The ultimate goal of this process is to promote the development of musical abilities of students through the use of specially selected and reworked musical works, which, influencing the child's affective sphere, are able to develop higher mental functions - thinking, will, motivation and enrich the children's musical experience that is necessary for further music education. It is stated that arranging is an effective means of developing the musical abilities of students of schools of aesthetic education in the guitar class, their thinking, general musical and inner hearing, memory, sense of form, sense of instrument, ensemble sense, and musicality.

The purpose of the article is to reveal the peculiarities of the processes of arranging, processing and translating musical guitar works for the development of the students' musical abilities.

Conclusions. 1. The main directions of arrangement: translation of the author's guitar works to another composition of performers; arrangements for guitar masterpieces of instrumental music; translation for guitar of solo vocal works; processing of mass and pop songs, jazz and pop hits, creation of potpourri and suites on their material; processing and rethinking of folk samples (folk songs); translations for guitar music into cartoons and feature films and computer games. 2. The use of arrangements for guitar allows teachers to focus their efforts on awakening the independent creativity of students of schools of aesthetic education, on the gradual discovery and development of the children's musical abilities and professional growth of their teacher-arranger. 3. Translation of instrumental, vocal, orchestral works for guitar is a creatively active work related to solving aesthetic problems.

Keywords: an arrangement; music education; translation of musical works; guitar music; processing of guitar works.

П остановка проблеми. Важливими цілями навчання у виші є розвиток у майбутніх учителів музики здатності засвоювати і застосовувати знання, виявляти творчі здібності учнів музичних шкіл та шкіл естетичного виховання в ході активної діяльності самого учня.

Останнім часом в педагогічній освіті часто піднімаються питання про невідповідність вимог, що висуваються до особистості вчителя та його 


\section{ПРОБЛЕМА СУЧАСНОГО АРАНЖУВАННЯ ТА ПЕРЕКЛАДАННЯ ГІТАРНИХ ТВОРІВ}

діяльності й фактичною готовністю до виконання ним своїх функцій.

Невирішеними раніше частинами проблеми вважаємо протиріччя, що обумовлюють необхідність вирішення проблеми цілеспрямованої підготовки та оновлення організаційних форм та методів в підготовці майбутніх учителів музики з метою формування у них готовності до подальшої професійної діяльності.

Актуальність проблеми. Більшість вітчизняних науковців вважають, що направляючу роль в фаховій підготовці студентів відіграють індивідуальні здібності, до яких можна віднести як загальні так і спеціальні музичні здібності (слух, ритм, емоційне сприйняття та ін.), які він потім має розвивати в учнів даючи їм не лише теоретичні знання, а й навчаючи за допомогою музичних творів, авторської інтерпретації, своїм творчим виконанням на музичному інструменті. Для досягнення цієї мети, майбутньому учителю музики необхідно займатися постійним самовдосконаленням, саморозвитком, поглиблювати набуті знання [7, 5].

Аналіз останніх досліджень та публікацій. Привертає увагу низка наукових досліджень культурологічного, музикознавчого та мистецтвознавчого напрямів, в яких зроблено важливі узагальнення. Характеристиці окремих його етапів присвячено наукові праці зарубіжних дослідників: О. Девуцького, В. Мартинова, Є. Месснера, Д. Нізяєва та ін.; особливості аранжування й перекладання гітарних творів розкриває вітчизняний дослідник О. Солдатенко $[1 ; 3 ; 4 ; 5 ; 7]$. Однак потреба у поглибленому культурологічному аналізі сучасного аранжування та перекладання гітарних творів в Україні потребує системного вивчення.

Мета статті - розкрити особливості процесів аранжування, обробки та перекладання музичних гітарних творів для розвитку музичних здібностей учнів.

Виклад основного матеріалу. Вітчизняні мистецтвознавці відмічають важливість євроінтеграції сучасного естрадного мистецтва України, зокрема їхні твори акцентують увагу на розвиток сучасної музичної освіти. Музична освіта $€$ частиною національної культури та одним iз визначальних факторів прогресу українського суспільства, формування національної ідентичності. Цей процес сприяє як демократизації суспільства, так й всебічному розвитку особистості $[2,35]$. В умовах музичної освіти це виявляється в опануванні такими вміннями, як: “залучення внутрішнього слуху; вільне читання нотного тексту; керівництво аплікатурними принципами і правилами групування ритму; орієнтація при грі на нотний текст; запам'ятовування, емоційне сприйняття музики; виконавська техніка; художнє мислення; застосування різних прийомів звукового видобування; володіння виконавським репертуаром, що включає твори різних жанрів, форм, стилів; виконання музики про дітей і для дітей; творча інтерпретація музичного твору; грати в ансамблі; працювати над ансамблевими аранжуваннями; робити сольні аранжування; грати етюди; застосовувати різноманітні технічні засоби сучасного звуковираження; спиратися на основні поняття, що використовуються в комп'ютерному аранжуванні; використовувати звукові карти, апаратні засоби, процесори ефектів і віртуальні музичні інструменти; користуватися допоміжними музичними програмами та працювати 3 музичним матеріалом (зведення, мастеринг); використовувати нотні редактори для створення музичних аранжувань і нотних партитур" [7, 6].

Майбутній вчитель музики є суб'єктом педагогічної діяльності та має володіти знаннями щодо індивідуальних та типологічних особливостей розвитку психіки учнів, їхніх потенційних можливостей та здібностей; вміти діагностувати, прогнозувати, моделювати, планувати організовувати навчально-виховний процес; розвивати: музично-естетичні здібності в учнів (емоційний відгук на музику); сенсорнопізнавальні музичні здібності (мелодійний, тембровий, динамічний, гармонійний слух, відчуття висоти звуку та ладу, чуття ритму); інтелектуальні музичні здібності (музичнообразне мислення; музично-репродуктивна та творча уява; музична пам'ять); засвоїти принципи, зміст, форми та методи навчання i виховання учнів $[7,6]$.

У нашому дослідженні маємо зосередитися на комп'ютерних програмах, що пропонуються як новий інструмент педагогічної діяльності викладача гітари в музичній школі. Важливо також розглянути гітарні аранжування в розвитку музичних здібностей учнів та врахувати рівень підготовки майбутніх викладачів (виконавський, художній та технічний рівні), схильність до певного стилю музики (класична, народна, естрадна), професійну орієнтацію. Це дає можливість майбутньому педагогу отримати відомості про найбільш раціональне застосування сучасних технічних та інформаційних засобів навчання в музичній школі та орієнтує його на організацію навчального процесу в напрямі широкого 
застосування активних форм і методів навчання. Музичний гітарний репертуар та авторські аранжування різноманітних музичних творів за різними жанрами, формою та характером і рівнем складності розраховані на їхнє професійне використання в роботі з учнями шкіл естетичного виховання.

Розглянемо також обробку та перекладання авторської музики й значення аранжування в розвитку музичних здібностей учнів. О. Девуцький, розглядаючи аранжування зазначає, що “динаміка i напрям культурного розвитку сучасного суспільства цілком виразно вказує на те, що в майбутньому питома вага різних обробок і перекладень авторської і традиційної фольклорної музики буде неухильно зростати, так само як роль аранжувальника серед інших музичних професій” $[3,50]$.

Вітчизняний дослідник О. Солдатенко вважає, що “навчання учнів шкіл естетичного виховання на відділенні народних інструментів по класу гітари вимагає від вчителя вмінь розписувати музичний матеріал, робити авторські обробки, компонування п'єс, аранжування" [7, 33].

Маємо погодитися 3 вітчизняним науковцем О. Солдатенко, який вважає, що “застосування аранжування для розвитку музичних здібностей учнів визначається самим музичним життям, його різнобічною практикою, потребами постійного активного оновлення педагогічного репертуару” $[7,33]$. Успішне навчання як учнів-початківців, так і вдосконаленням мистецтва майбутніх вчителів потребує спеціальної підготовки. Кінцевою метою цього процесу є сприяння розвитку музичних здібностей учнів через використання спеціально відібраних і перероблених музичних творів, які, впливаючи на афективну сферу дитини, здатні розвивати у неї вищі психічні функції- мислення, волю, мотивацію та збагачувати музичний досвід дітей. Що є необхідним для подальшої музичної освіти.

Можна стверджувати, що аранжування $\epsilon$ дієвим засобом розвитку музичних здібностей дитини, їі мислення, загально-музичного і внутрішнього слуху, пам'яті, відчуття форми, чуття інструменту, ансамблевого чуття, музичності. Це суттєво як для учнів з гарними, так і з посередніми музичними здібностями враховуючи те, що аранжування дає новий поштовх для їхнього розвитку як в музичній освіті, так й в естетичній.

Поширена практика гітарних аранжувань породжується сформованим об'єктивним станом речей, коли як учні, так і майбутні вчителі музики воліють виконувати скоріше знайому для них популярну музику, ніж твори хоч і сучасних, але маловідомих авторів. Ми вважаємо, що викладачі шкіл естетичного виховання відчувають хронічний дефіцит педагогічного репертуару, який би створював більш сприятливу атмосферу для музичної освіти учнів.

Наше дослідження доводить, що якщо учень хоче виконати якусь музику на гітарі, то має два варіанти: або їі просто заспівати під акомпанемент гітари, або зіграти на гітарі як самостійний інструментальний твір. Цей процес є особливо складним для учнів-початківців. Щоб заспівати потрібно лише підібрати акорди до пісні, зіграти ïx на гітарі певним способом і співати. Інша річ, якщо треба зіграти музичний твір в інструментальному варіанті, де на одній гітарі грається і партія голосу (мелодія ), і партія басу, i партії гармонії з ритмічним супроводом. Для цього потрібні ноти твору для гітари, які треба написати і об'єднати кілька партій пісні в одну партію гітари. Самостійно це зробити можна лише за наявності хороших знань в області музичної теорії, гармонії, композиції, маючи розвинений музичний слух і в достатній мірі володіючи інструментом (вище середнього рівня), та маючи чималий музичний досвід. Цим займаються гітаристи-аранжувальники $[3,48 ; 4,36 ; 6]$.

На думку вітчизняного дослідника О. Солдатенка, “систематичне застосування спеціально дібраних і перероблених музичних творів викликає у дітей активний інтерес до музики, до завдань і сприяє швидкому оволодінню дітьми музичним репертуаром. Професійне навчання гри на гітарі здійснюється з урахуванням індивідуальних особливостей учнів (віку, темпераменту, моторного профілю та ін.) через активні методи навчання на доцільно і методично правильно підібраному репертуарі, у поєднанні індивідуальних (сольне виконання) та групових (гра в ансамблі) форм роботи" [7, 35].

Д. Нізяєв вважає, що “аранжування - це будь яке переосмислення або переоформлення музичного матеріалу, але в межах розпізнавання оригіналу. Це майже композиторство, бо справжній композитор вигадує тільки одну мелодію або навіть мотив, все інше залежить від його вміння аранжувати, оформити цю думку” [5].

М. Чигинцев [8], як практик-аранжувальник, наводить алгоритм аранжування для гітари та виділяє наступні етапи: “підбір на слух (головна мелодія і гармонійна схема (акорди) пісні); аранжування (пошук тональності аранжування; визначення фактури і форми аранжування; написання басової лінії, пошук позицій на грифі та оптимальної аплікатури; розробка варіацій для 
повторів; написання вступу, переходів між частинами, закінчення; набір аранжування в нотах і табулятурі; відпрацювання виконання, запис на відео" [8].

На нашу думку, сучасна техніка виконання аранжування включає також володіння комп'ютером та мідіклавіатурою як необхідними засобами для запровадження та використання звукової інформації за допомогою програм "Finale", "Sibelius" та ін. Це дозволяє інтенсифікувати процес аранжування, поліпшити якість виконуваних робіт і дає можливість значно розширити спектр використання музичного матеріалу аудіо-відеозаписів і нотного тексту 3 застосуванням нотування комп'ютерними програмами типу "Wavelab".

Важливо пам'ятати, що намагаючись якісно розвити музичні здібності учнів, гітарні педагогиаранжувальники активно працюють в декількох основних напрямах, затребуваних часом, а саме: перекладення авторських гітарних творів на інший склад виконавців; перекладення для гітари шедеврів інструментальної музики; перекладення для гітари сольних вокальних творів; обробка масових та естрадних пісень, джазових і поп-хітів, створення попурі і сюїт на їх матеріалі; обробка та переосмислення фольклорних зразків (народних пісень); перекладення для гітари музики до мультиплікаційних та художніх кінофільмів і комп'ютерних ігор $[7,36]$.

Для нашого дослідження також важливо розглянути перекладання музичних творів для гітари. Цей процес вимагає від педагогааранжувальника не стільки майстерності, скільки відомої частки уважності та технологічної винахідливості в пристосуванні твору до музичних здібностей конкретного учня, його потреб, виконавських можливостей (як правило, невисоких), або зміни складу ансамблю чи оркестру. Вважаємо, що підбір аранжувань творів для шестиструнної гітари, що дозволяє створити атмосферу творчих шукань студентів для розвитку музичних здібностей учнів, підняття їхнього рівню виконавства на гітарі, отримання насолоди від програвання спеціально дібраних і перероблених вже знайомих їм музичних творів, та зацікавлення новими інструментальними і вокальними творами із складнішим розвитком музичного образу, підтримування у дітей бажання співати, виховуючи любов до пісні, залучення учнів до імпровізації і ансамблевого музикування, яке розвиває гармонійний слух, ритм, почуття відповідальності.

Дослідники вважають, що перекладення інструментальних, вокальних, оркестрових творів для гітари - це творчо активна праця, пов'язана 3 розв'язанням безлічі художньо-естетичних завдань для повного розкриття і всебічного розвитку музичних здібностей учнів здебільше старшого віку та студентів. Наприклад: “Річкові потоки в тобі” I. Рума; “Старовинна Французька Пісня” невідомий композитор.

Перекладення для гітари сольних вокальних творів поєднує в собі принципи перекладення інструментальної музики (у разі перенесення музичного супроводу в гітарні партії) та обробки народних пісень (вибір словесного тексту куплетів, підтекстів вокальних партій) і сприяє розвитку як виконавських спеціальних музичних здібностей учнів (наприклад, для співака це наявність красивого за тембром голосу і здібності керувати ним), так i композиторських. Ілюстрацією цього є: “Мне нравится, что Вы больны не мной” (М. Таривердієв музика з фільму: “Ирония Судьбы или с легким паромо). Обробка популярних, естрадних та джазових пісень на сьогоднішній момент вельми затребувана так, як в реальній практиці нерідко виникає потреба у створенні розважальних, гротескових, змістовно спрощених зразків музичних творів (естрада, театр, кіно, телебачення), іiї написання не стільки підкорюється принципам гітарного аранжування, скільки розвиває спеціальні музичні здібностей учнів, пов'язані зі специфікою естрадного виконання.

Також вельми затребувана в гітарному мистецтві обробка народних пісень, створення вільних пісенних композицій, що сприяє всебічному розвитку композиторських здібностей учнів, виховуючи любов до пісні і розуміння сучасності та непідвладності часу народної творчості. Підтвердженням цього є такі твори: “Веселі каченятао - попурі за мотивами російської народної пісні “Два веселых гуся” з мультфільму “Веселая карусель” і швейцарської пісні Т. Вернера “Танець каченят”; “Ніч яка місячна” - українська народна пісня; “Ти ж мене підманула” - українська народна пісня; “Щедрик”- обробка М. Леонтовича, українська народна пісня.

Перекладення для гітари музики до мультиплікаційних та художніх кінофільмів і комп'ютерних ігор особливо актуальне для учнів молодших і середніх класів шкіл естетичного виховання, і $є$ дієвою мотивацією до регулярних занять, що, у свою чергу, сприяє поступовому розкриттю і розвитку музичних здібностей дітей та професійному росту їхнього педагогааранжувальника. До них належать: “Wind” (Вітер) Ш. Фукуда, музика з гри “Asura's Wrath”; "Downstream" (Вниз за течією) Ш. Каммен, 


\section{ПРОБЛЕМА СУЧАСНОГО АРАНЖУВАННЯ ТА ПЕРЕКЛАДАННЯ ГІТАРНИХ ТВОРІВ}

музика з гри “Braid”; “Джеймс Бонд” М. Норман, музика з фільму “Джеймс Бонд”; “Кантіна” Д. Уільямс, музика з фільму “Зоряні війни” та інші.

Висновки. 1. Основні напрями аранжування: перекладення авторських гітарних творів на інший склад виконавців; перекладення для гітари шедеврів інструментальної музики; перекладення для гітари сольних вокальних творів; обробка масових та естрадних пісень, джазових і поп-хітів, створення попурі і сюїт на їх матеріалі; обробка та переосмислення фольклорних зразків (народних пісень); перекладення для гітари музики до мультиплікаційних та художніх кінофільмів і комп'ютерних ігор. 2. Використання аранжування для гітари дозволяє спрямувати зусилля викладачів на пробудження самостійної творчості учнів шкіл естетичного виховання, на поступове розкриття і розвиток музичних здібностей дітей та професійний ріст їхнього педагога-аранжувальника. 3. Перекладання інструментальних, вокальних, оркестрових творів для гітари - це творчо активна праця, пов'язана 3 вирішенням естетичних завдань.

Перспективами подальших наукових розвідок вважаємо вивчення процесу обробки та аранжування музичних творів, що $є$ сольним і ансамблевим репертуаром для учнів молодших класів музичних шкіл, які займаються по класу гітари.

\section{ЛІТЕРАТУРА}

1. Девуцкий О. В. Теоретические аспекты искусства хоровой аранжировки: дис. ... канд. искусствоведения : 17.00.02. Москва, 2006. 168 с.

2. Дружинець М. Процеси євроінтеграції сучасного естрадного мистецтва: київські музичні заклади вищої освіти. Актуальні питання гуманітарних наук. 2018. Вип. 20. Т. 2. С. 34 38.

3. Мартынов В. Конец времени композиторов. Послесл. Т. Чередниченко. Москва: Русский путь, 2002. $296 \mathrm{c}$.

4. Месснер Е. Основы композиции. Москва: Музыка, 1968. 503 с.

5. Низяев Д. Аранжировка. URL: http:// www.7not.ru/arrange/ (дата звернення 25.07.2020).

6. Особенности обучения аранжировке для студентов-народниковисполнительских специальностей. URL: http://urokimusic.com/online-shkola- urokimusic/ obuchenie-aranzhirovke-2/ (дата звернення 25.07.2020).
7. Солдатенко О. І. Комп'ютерні технології та гітарні аранжування в розвитку музичних здібностей учнів: навч.-метод. посіб. для вчителів та учнів шкіл естет. вихов. Чернігів: Видавець Лозовий В.М., 2015. 88 с.

8. Чигинцев М. О профессии аранжировщика для гитары. URL: http://4igi.ru/217- pochemu-yaprodayu-noty-o-professii-aranzhirovshchika-dlyagitary. (дата звернення 25.07.2020).

\section{REFERENCES}

1. Devuckij, O. V. (2006). Teoreticheskie aspekty iskusstva horovoj aranzhirovki [Theoretical aspects of the art of choral arrangement]. Candidate's thesis. Moscov, 168 p. [in Russian].

2. Druzhynecj, M. (2018). Procesy jevrointeghraciji suchasnogho estradnogho mystectva: kyjivsjki muzychni zaklady vyshhoji osvity [Processes of European integration of modern pop art: Kyiv music institutions of higher education]. Current issues of the humanities. issue 20. Vol. 2, pp.34-38. [in Ukrainian].

3. Martynov, V. (2002). Konec vremeni kompozitorov [The end of the composers' time]. (Ed.). T. Cherednichenko. Moscov, 296 p. [in Russian].

4. Messner, E. (1968). Osnovy kompozicii [Composition basics]. Moscov, 503 p. [in Russian].

5. Nizjaev, D. (2020). Aranzhirovka [Arrangement]. Available at: http://www.7not.ru/arrange/ (accessed 25 July 2020). [in Russian].

6. Osobennosti obuchenija aranzhirovke dlja studentov-narodnikov ispolnitel'skih special'nostej (2020). [Features of teaching arrangement for students-populists performing specialties]. Available at: http://urokimusic.com/online-shkola- urokimusic/ obuchenie-aranzhirovke-2/ (accessed 25 July 2020). [in Russian].

7. Soldatenko, O. I. (2015). Kompjuterni tekhnologhiji ta ghitarni aranzhuvannja v rozvytku muzychnykh zdibnostej uchniv [Computer technology and guitar arrangements in the development of students' musical abilities]. Educational and methodical manual for teachers and students of schools of aesthetic education. Chernighiv, 88 p. [in Ukrainian].

8. Chigincev, M. (2020). O professii aranzhirovshhika dlja gitary [About the profession of a guitar arranger]. Available at: http://4igi.ru/217pochemu-ya-prodayu-noty-o-professiiaranzhirovshchika-dlya-gitary. (accessed 25 July 2020). [in Russian].

Стаття надійшла до редакції 03.06.2020 